\title{
Clinical and Diagnostic Significance of Aspartate Aminotransferase Isoenzymes in Sera of Patients with Liver Diseases
}

\author{
By M. Panteghini, A. Malchiodi, M. Calarco and R. Bonora \\ 1 st Laboratory of Clinical Chemistry, Spedali Civili, Brescia, Italy
}

(Received May 30/September 23, 1983)

Summary: Serum aspartate aminotransferase isoenzymes were measured in 123 hospital patients with various liver diseases, using a new and simple immunochemical method.

Our findings show the usefulness of this determination in estimating the severity of hepatic damage, especially if accompanied by the measurement of other mitochondrial enzymes.'During hepatic damage, the cytoplasmic isoenzyme is found in greater quantities than the mitochondrial isoenzyme, but the level of the latter increases to a greater extent in acute liver diseases. Moreover, the values of mitochondrial aspartate aminotransferase activity and the ratio of mitochondrial to total aspartate aminotransferase in alcoholic hepatitis are higher than expected if so-called hepatic enzymes commonly measured in serum are considered. These results indicate that there is significant mitochondrial damage in alcoholic hepatitis.

Klinische und diagnostische Bedeutung von Aspartataminotransferase-Isoenzymen im Serum von Patienten mit Lebererkrankungen.

Zusammenfassung: Die Isoenzyme von Aspartataminotransferase im Serum wurden mit einer neuen und einfachen immunchemischen Methode bei 123 Krankenhauspatienten mit verschiedenen Lebererkrankungen bestimmt.

Unsere Ergebnisse zeigen die Nützlichkeit dieser Bestimmung für die Feststellung des Schweregrades der Leberschädigung, besonders, wenn gleichzeitig andere mitochondriale Enzyme bestimmt werden. Während einer Leberschädigung ist das cytoplasmatische Isoenzym in größerer Menge als das mitochondriale Isoenzym nachweisbar. Dieses steigt jedoch bei ạuten Lebererkrankungen an. Darüberhinaus sind die Werte für mitochondriale Aspartataminotransferase-Aktivität und das Verhältnis von mitochondrialer zu gesamter Aspartataminotransferase bei alkoholbedingter Hepatitis höher als erwartet, wenn die sogenannten, üblicherweise im Serum bestimmten Leberenzyme betrachtet werden. Die Ergebnisse zeigen, daß bei alkoholbedingter Hepatitis eine bedeutende mitochondriale Schädigung besteht.

\section{Introduction}

Serum total aspartate aminotransferase has been .widely studied, as an optimal index for hepatic diseases. However, it is known that this index does not necessarily coincide with the intensity of liver cell damage (1).

Recently, several studies have demonstrated the presence of both cytoplasmic and mitochondrial as- partate aminotransferases (EC 2.6.1.1), (2-6), which differ in their amino acid composition and in their immunochemical and kinetics properties (79).

As early as 1967 , Schmidt et al. (10) started to consider the possible clinical usefulness of measuring of these isoenzymes. Until recently, measurement of these isoenzymes was not widely applied for clinical 
purposes, chiefly because the methods (electrophoresis $(2-4)$, column chromatography $(10,11))$ were tedious, slow, imprecise and inaccurate, and not adaptable for routine use. Recent publications $(12-16)$ have described immunochemical procedures, based on the use of antibodies directed against the two aspartate aminotransferase isoenzymes. The introduction of these new immunochemical methods has simplified and improved the sensitivity of the isoenzymic assays.

In previous work $(16,17)$, we tried to establish a possible relationship between the aspartate aminotransferase isoenzyme composition of human serum and the degree of hepatic damage. This paper represents the conclusive results of a study of 123 patients with various liver diseases, performed over a period of sixteen months.

\section{Materials and Methods}

123 patients were studied; these were admitted to the 4 th Division of Medicine and to the Infectious Diseases Division of the Civil Hospital of Brescia, over a period of sixteen months (19811982). The patients were divided, on the basis of anamnestic, histologic and diagnostic data, into the following groups:

(a) acute viral hepatitis (28 cases, mean age $30 \pm 20$ years);

(b) alcoholic hepatitis (30 cases, $48 \pm 7$ years);

(c) active chronic hepatitis (14 cases, $36 \pm 10$ years);

(d) persistent chronic hepatitis (14 cases, $34 \pm 12$ years);

(e) primary and secondary neoplastic disease of the liver (11 cases, $58 \pm 9$ years);

(f) hepatic cirrhosis (26 cases, $52 \pm 9$ years).

In addition, 50 healthy volunteers were studied in order to establish the reference level of aspartate aminotransferase isoenzymes in serum. Serum samples were obtained from laboratory workers with normal serum biochemical and haematological tests and without clinical evidence of liver, pancreatic, cardiac and muscle diseases ( 25 women and 25 men, whose ages ranged from 20 to 45 years, average $30 \pm 6$ years). The unhaemolysed sera were frozen at $-60^{\circ} \mathrm{C}$ within $2 \mathrm{~h}$ of collection and used within two days. Stability studies confirmed that the activities of examined enzymes and isoenzymes were unaltered during storage for this period.

The following examinations were carried out in duplicate on all the subjects: aspartate aminotransferase (18), alanine aminotransferase (18), $\gamma$-glutamyl transpeptidase (19), ornithine carbamyl transferase (20) and glutamic dehydrogenase (21). Enzyme activity concentrations are expressed in terms of $U / 1$ serum ( $1 \mathrm{Un}$ it $=1 \mu \mathrm{mol}$ substrate converted per minute under optimal conditions) measured at $37^{\circ} \mathrm{C}$. An immunochemical method $(15,16)$ was used for the determination of aspartate aminotransferase isoenzymes: the serum specimen is incubated with sheep red blood cells, which have anti-human soluble aspartate aminotransferase antibodies adsorbed to their surface; the cytoplasmic isoenzyme of aspartate aminotransferase is adsorbed on red cell, thus permitting elimination of this isoenzyme by centrifugation. In the surnatant the residual aminotransferase activity corresponds to the mitochondrial isoenzyme and is determined with same methodology described for the total enzyme (18). Cytosolic activity is estimated by difference. A lyophilised serum, obtained from Poli
Industria Chimica, Milan, Italy, with a mean value of $130 \mathrm{U} / \mathrm{S}$ for the mitochondrial enzyme and $1300 \mathrm{U} / \mathrm{h}$ for the soluble isoenzyme, was used for quality control. Since no recognized reference method exists for the determination of aspartate aminotransferase isoenzymes, we have selected the immunoprecipitation technique of $R e j(13)$, involving anti-human soluble isoenzyme rabbit antibodies, as the comparative method for our procedure. Correlation between the two techniques was excellent, with " $r$ " value of 0.994 $(y=0.92 x-0.21)$.

All the enzymatic determinations, except ornithine carbamyl transferase, were carried out on a Cobas Bio centrifugal analyzer (F. Hoffman La Roche and Co., Ltd., Basle, Switzerland). The ornithine carbamyl transferase activity was determined by a manual procedure (20), using a LKB 7400 Calculating Absorptiometer (LKB Produckter AB, Bromma, Sweden). Since values for the serum enzymes were not normally distributed, the statistical analyses were performed with non-parametric statistical tests (Wilcoxon rank-sum test) (22).

\section{Results}

The results of enzyme and isoenzyme determinations, in different patients groups and in healthy volunteers, expressed as median values, are summarized in table 1. Figure 1 shows the levels of mitochondrial isoenzyme of aspartate aminotransferase in various liver diseases.

The differences between the patient groups were not always significant; the behaviour and discriminative capacity of cytosolic isoenzyme are very similar to those of total aspartate aminotransferase, while the mitochondrial isoenzyme is a better discriminator for separating acute viral hepatitis from the other hepatic diseases. In acute hepatitis, marked changes are observed in the mitochondrial isoenzyme levels: in patients with higher relative proportions of mitochondrial isoenzyme, the recovery tended to be delayed, while in most of the patients with low values of mitochondrial aspartate aminotransferase activity, the liver function returned to normal within a few weeks. The behaviour of this isoenzyme, in the course of acute hepatitis, is the same as that of the alanine aminotransferase, ornithine carbamyl transferase and glutamic dehydrogenase. This is to be expected since ornithine carbamyl transferase and glutamic dehydrogenase, as well as mitochondrial aspartate aminotransferase, are localized exclusively in the mitochondrium and leak into serum only when liver cells are severely damaged.

Important data emerged from the analysis of patients with alcoholic hepatitis: total transaminase activities are only moderately raised, but considerably higher proportions of mitochondrial aspartate aminotransferase are found in the serum. In this condition, the essential lesion is a focal liver cell necrosis with polymorphonuclear leukocyte - infiltrate and varying degrees of fibrosis (23). 
Tab. 1. Enzyme and isoenzyme median values*) in serum of patients with various hepatic diseases and in healthy volunteers.

\begin{tabular}{|c|c|c|c|c|c|c|c|c|}
\hline & & $\begin{array}{l}\text { Acute } \\
\text { viral } \\
\text { hepatitis }\end{array}$ & $\begin{array}{l}\text { Alcoholic } \\
\text { hepatitis }\end{array}$ & $\begin{array}{l}\text { Active } \\
\text { chronic } \\
\text { hepatitis }\end{array}$ & $\begin{array}{l}\text { Persist- } \\
\text { ent } \\
\text { chronic } \\
\text { hepatitis }\end{array}$ & $\begin{array}{l}\text { Liver } \\
\text { neo- } \\
\text { plasia }\end{array}$ & $\begin{array}{l}\text { Hepatic } \\
\text { cirrhosis }\end{array}$ & Controls \\
\hline Total aspartate aminotransferase & $(\mathrm{U} / \mathrm{l})$ & 387 & 62 & 241 & 66 & 65 & 62 & 17 \\
\hline Soluble aspartate aminotransferase & $(\mathrm{U} / 1)$ & 352 & 55 & 223 & 63 & 60 & 62 & 17 \\
\hline Mitochondrial aspartate aminotransferase & $(\mathrm{U} / \mathrm{l})$ & $\left.29.5^{* *}\right)$ & 7.1 & 9.0 & 2.9 & 6.4 & 0.7 & 0.7 \\
\hline Alanine aminotransferase & $(\mathrm{U} / 1)$ & $592 * *)$ & 36 & $159 * *)$ & 60 & 35 & 24 & 13 \\
\hline Ornithine carbamyl transferase & $(\mathrm{U} / \mathrm{l})$ & $\left.68.5^{* *}\right)$ & 26.0 & 18.1 & 10.0 & 18.7 & 5.0 & 5.0 \\
\hline Glutamic dehydrogenase & $(U / I)$ & $\left.19.8^{* *}\right)$ & 12.0 & 12.1 & 3.6 & 10.5 & 2.2 & 1.2 \\
\hline$\gamma$-Glutamyltranspeptidase & $(\mathrm{U} / \mathrm{I})$ & 146 & 249 & 58 & 58 & 512 & 79 & 11 \\
\hline
\end{tabular}

*) All values are expressed in $U / 1$ (see 'Materials and methods').

**) Significantly different value from other hepatic diseases $(p<0.01)$.

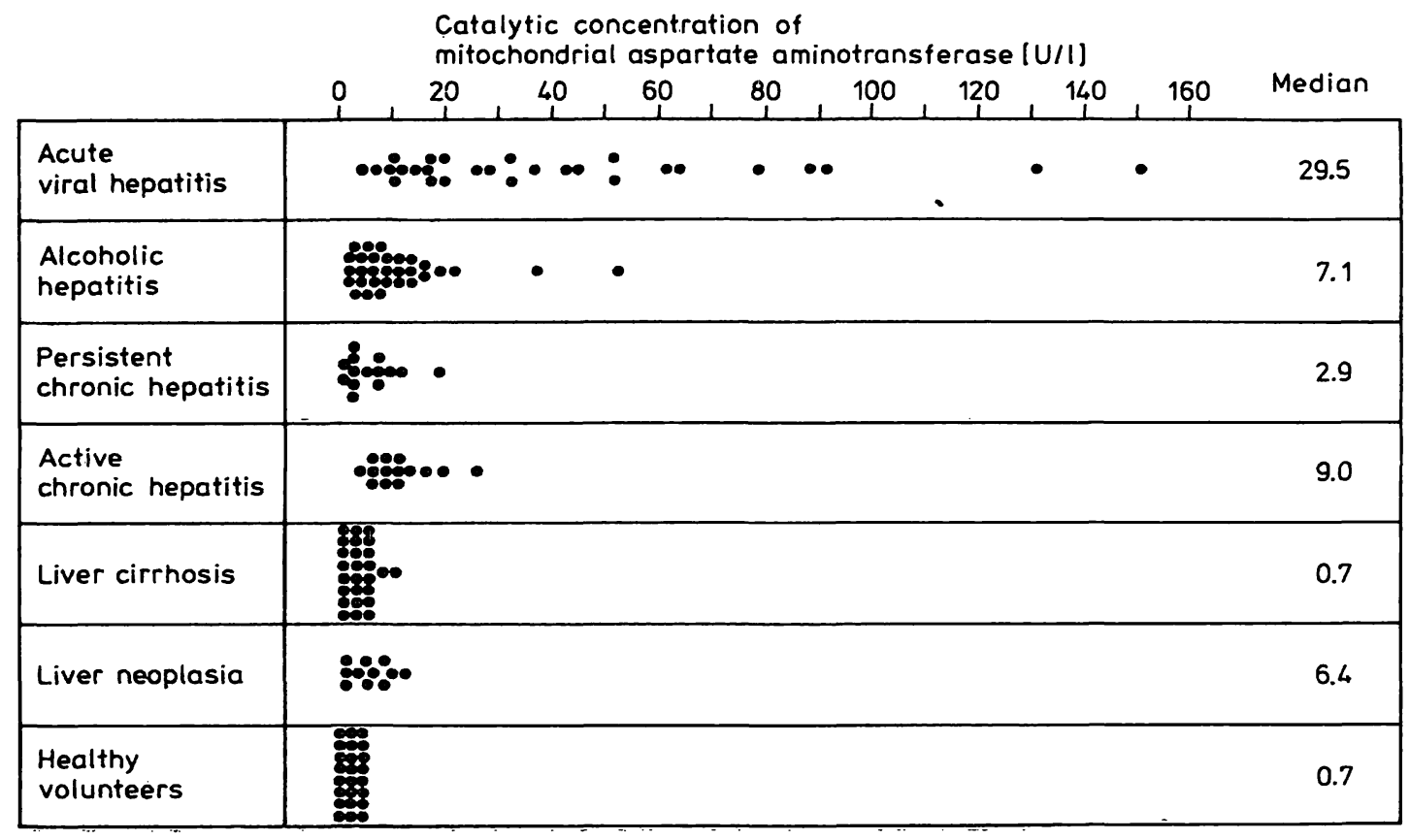

Fig. 1. Mitochondrial aspartate aminotransferase levels in various liver diseases.

Figure 2 shows the ratio between mitochondrial and total aspartate aminotransferase in various hepatic diseases: about $30 \%$ of alcoholic hepatitis cases show values exceeding $14 \%$, while in all other groups it is considerably lower. This therefore helps to discriminate between alcoholic hepatitis and all other liver pathologies under consideration.

These results seem to demonstrate that there could be a mitochondrial aspartate aminotransferase induction by alcohol. Mitochondrial aspartate aminotransferase values are higher than would be expected from the corresponding histological necrotic picture.

The hypothesis (24-26) that enzymatic induction is a significant factor in the alcoholic liver diseases was investigated by the contemporaneous study of two mitochondrial enzymes, glutamic dehydrogenase and ornithine carbamyl transferase, which are notoriously associated with deep cellular damage $(27,28)$. In alcoholic hepatitis, there is a positive correlation between mitochondrial aspartate aminotransferase and ornithine carbamyl transferase $(r=0.894 ; p$ $<0.001)$ and between mitochondrial aspartate aminotransferase and glutamic dehydrogenase $(r=$ $0.600 ; \mathrm{p}<0.001$ ).

Thus, these results indicate significant mitochondrial damage in alcoholic hepatitis, and it is unlikely that the raised mitochondrial matrix enzymes represent merely an adaptive response to the ethanol load. 


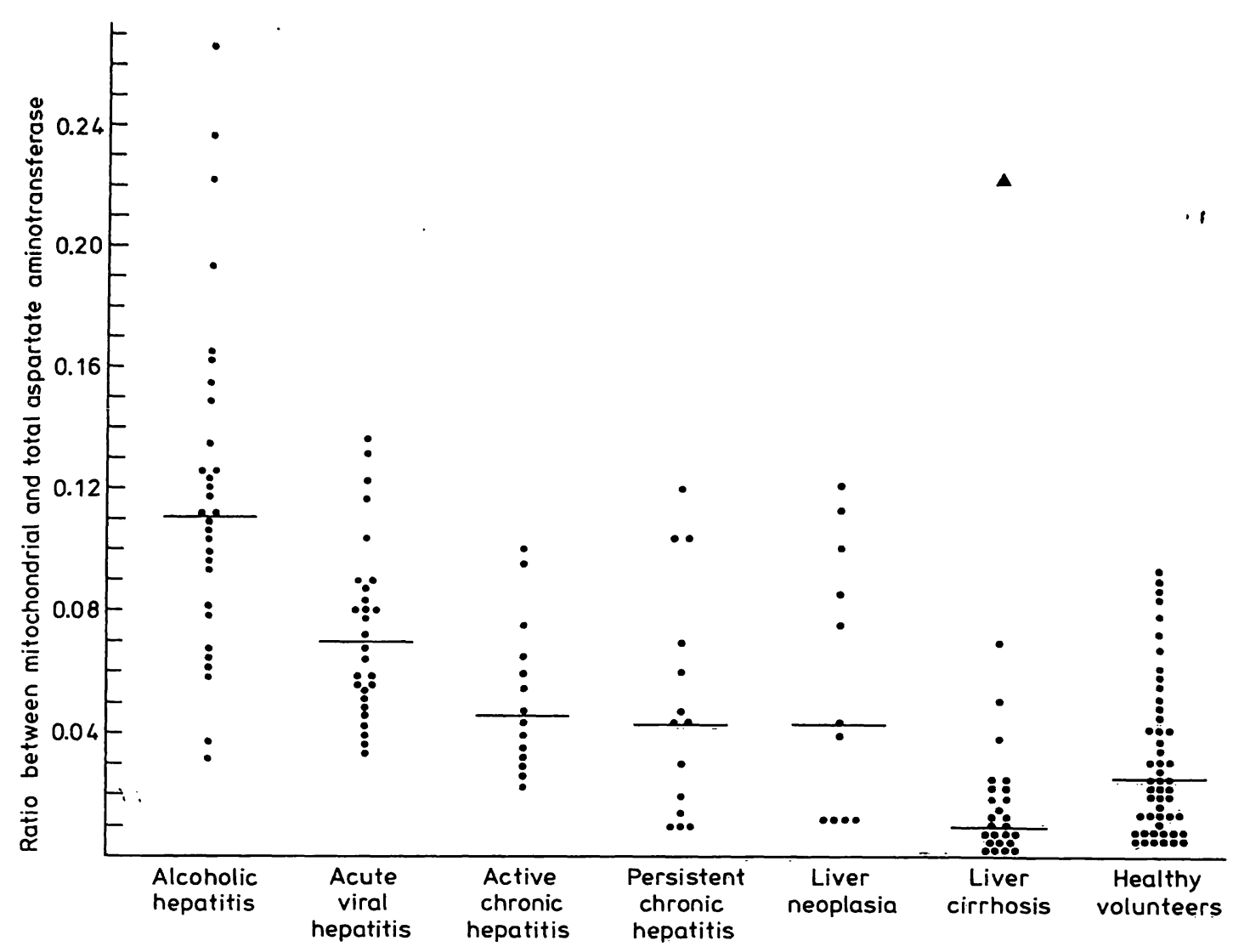

Fig. 2. The ratio (median values in percentage) between mitochondrial and total aspartate aminotransferase in hepatic diseases and in healthy volunteers. The difference between alcoholic hepatitis and other hepatic diseases is statistically significant $(p<0.05)$. Solid triangle: liver cirrhosis and accidental trauma with wide haematomas of the pelvis and inferior limbs.

\section{Discussion}

Fleisher et al. $(3,4)$ found human serum to contain two types of aspartate aminotransferase. This finding was confirmed by subsequent enzymologic studies $(2,5,6)$, which demonstrated the existence of a cytoplasmic or soluble isoenzyme of aspartate aminotransferase and a mitochondrial one. Later, other authors $(7,8,29)$ reported that these two forms have different immunochemical behaviour, due to slight differences in their protein structures $(9,30)$.

The major component in normal sera is the cytoplasmic isoenzyme (median value, $17 \mathrm{U} / 1$ ), while sera from healthy people show very low activities of the mitochondrial isoenzyme (median value, $0.7 \mathrm{U} / \mathrm{l}$ ). Our data confirm those of other authors $(13,15,25)$, who found small quantities of mitochondrial aspartate aminotransferase in healthy subjects. The physiological significance of these isoenyzmes is unknown, but the presence of both isoenzymes in various organs suggests their importance in the aspartate-malate shuttle, which is responsible for the transport of reducing equivalents of nicotinamide adenine dinucleotide through the mitochondrial membrane. Moreover, if we consider that the two enzymes are located in the cytoplasm and mitochondria, respectively, then hepatic damage will release more of the soluble than the mitochondrial aspartate aminotransferase into the bloodstream.

The presence of the latter in the blood requires mitochondrial damage, which usually occurs only in a deep cellular necrosis, whereas the release of cytosolic isoenzyme is only due to an increase in permeability of the cell membrane. Indeed, this happens in various examined hepatic diseases (tab. 1): it is evident that mitochondrial isoenzyme levels increase much more in acute liver pathology (fig. 1). In patients with acute viral hepatitis, the subjects showing good clinical progress showed a relatively low value of mitochondrial aspartate aminotransferase activity. In contrast, recovery tended to be prolonged in patients with higher values of mitochondrial aspartate aminotranferase. This fact seems to indicate that the determination of serum mitochondrial aspartate aminotransferase as an important ińdex for judging 
the prognosis of acute liver diseases (31). In alcoholic hepatitis, mitochondrial aspartate aminotransferase values were much higher than expected, when so-called hepatic enzymes commonly measured in serum and anamnestic and histologic findings were taken into consideration. Moreover, the ratio of mitochondrial to total aspartate aminotransferase was significantly higher when compared with non-alcoholic liver diseases. Based on these facts, some authors $(24,25)$ have hypothesized that high values of mitochondrial aspartate aminotransferase in alcoholic hepatitis may be due to an induction in hepatic mitochondria by alcohol. In contrast, our conclusive data show significant mitochondrial damage in this liver pathology: mitochondrial aspartate aminotransferase seems to be specifically related to liver damage, in the same way as ornithine carbamyl transferase and glutamic dehydrogenase $(27,28)$; an increase of mitochondrial aspartate aminotransferase in serum therefore indicates a more severe injury of the hepatic cells. Furthermore, marked pathological changes have been observed in mitochondria of liver cells of alcoholics, due to the toxic effect of ethanol and its metabolites $(32,33)$; electron microscopic studies show swollen mitochondria with disorientated cristae (34). Also, in some cases, muscle damage (alcoholic myopathy), resulting in leakage of enzymes from myocytes, could be partially responsible for the relatively elevated activity of mitochondrial aspartate aminotransferase in alcoholic serum (35); but none of our patients with alcoholic hepatitis had overt clinical heart disease or symptomatic myopathy, which might have contributed to enzyme abnormalities. Therefore, we have shown the advantages of mitochondrial aspartate aminotransferase as a biochemical marker of liver necrosis. Higher proportions of mitochondrial aspartate aminotransferase are found in the serum of patients with acute liver diseases; higher activities of glutamic dehydrogenase and ornithine carbamyl transferase also occur in the sera in these conditions. In particular, the ratio of mitochondrial to total aspartate aminotransferase seems to identify very well the characteristic "necrotic type" condition named by Schmidt (10), i.e. a slight increase of the enzyme levels concomitant with relatively high activities of mitochondrial enzymes.

The practical implications of these results are evident. The new immunochemical procedures for the determination of aspartate aminotransferase isoenzymes are technically simple and specific, and the levels of these enzymes are reliable index of the presence or absence of liver cell necrosis. Estimation of aspartate aminotransferase isoenzymes should therefore be included in the investigation of hepatic diseases. In particular, a knowledge of the serum concentration of these isoenzymes could improve the identification of patients with active alcoholic liver disease, including those who are asymptomatic.

\section{Acknowledgements}

We are deeply grateful to Doctor Robert Rej (Albany, NY) for supplying the antiserum for the performance of his method. We thank the 4th Division of Medicine and the Infectious Diseases Division of the Civil Hospital of Brescia for help in these studies. We are grateful to Mrs. Adriana Giacomini for typing the manuscript.

\section{References}

1. Kallai, L., Mahn, A., Roder, V. \& Zupanic, V. (1964) Acta Med. Scand. 175, 49-56.

2. Boyd, J. W. (1961) Biochem. J. 81, 434-441.

3. Fleisher, G. A., Potter, C. S. \& Wakim, K. G. (1960) Proc. Soc. Exp. Biol. Med. 103, 229-231.

4. Fleisher, G. A. \& Wakim, K. G. (1961) Proc. Soc. Exp. Biol. Med. 106, 283-286.

5. Katunuma, N., Mạtzusawa, T. \& Huzino, A. (1962) J. Vitaminol. 8, 74-99.

6. Morino, Y., Itoh, H. \& Wada, H. (1963) Biochem. Biophys. Res. Commuñ. 13, 348-352.

7. Morino, Y., Kagamiyama, H. \& Wada, H. (1964) J. Biol. Chem. 239, 943-944.

8. Nisselbaum, J. S. \& Bodansky, O: (1964) J. Biol. Chem. 239, 4232-4236.

9. Wada, H. \& Morino, Y. (1964) Vitam. Horm. 22, 411-444.

10. Schmidt, E.; Schmidt, W. \& Otto, P. (1967) Clin. Chim. Acta 15, 283-289.

11. Sampson, E. J., Miller, S. A., McKneally, S. S., Whitner, V. S., Hannon, W. H. \& Burtis, C. A. (1978) Clin. Chem. 24, 1805-1812.

12. Rej, R. (1979) Clin. Biochem. 12, 250-254.

13. Rej, R. (1980) Clin. Chem. 26, 1694-1700.

14. Rej, R., Keese, C. R. \& Giaever, I. (1981) Clin. Chem. 27, 1597-1601.

15. Wada, H., Teranishi, H., Kagamiyama, H., Ohyanagi, H., Shirakawa, M., Mitzuno, T., Fuse, K. \& Sawada, Y. (1978) Med. J. Osaka University 29, 181-189.

16. Panteghini, M., Falsetti, F., Chiari, E. \& Malchiodi, A. (1983) Clin. Chim. Acta 128, 133-140.

17. Panteghini, M., Falsetti, F., Chiari, E. \& Malchiodi, A. (April 1982) Presented at the 10th International Symposium on Clinical Enzymology. Abano Terme. Italy.

18. The Committèe on Enzymes of the Scandinavian Society for Clinical Chemistry and Clinical Physiology (1974) Scand. J. Clin. Lab. Invest. 33, 291-306.

19. Rosalki, S. B. \& Tarlow, D. (1974) Clin. Chem. 20, 11211124.

20. Ceriotti, G. (1973) Clin. Chim. Acta 47, 97-105.

21. Schmidt, E. (1970) in: Methoden der enzymatischen Analyse (Bergmeyer, H. U. ed.), Vol. I, 2nd ed., 607, Verlag Chemie, Weinheim. 
22. Armitage, P. (1971) Statistical methods in medical research. Wiley, New York.

23. Alcoholic liver disease: morphological manifestations. Review by an International Group (1981) Lancet $I, 707-711$.

24. Jenkins, W. J. \& Peters, T. J. (1978) Gut 19, 341-344.

25. Sekiya, C., Yasaki, Y., Numazaki, A., Takanashi, A., Takasugi, Y., Namiki, M., Mima, S., Hanyu, T. \& Tanabe, Y. (1979) Hokkaido J. Med. Sci. 5, 245-251.

26. Jenkins, W. J., Rosalki, S. B., Foo, Y., Scheuer, P. J., Nemesanszky, E. \& Sherlock, S. (1982) J. Clin. Pathol. 35, 207210.

27. Konttinen, A., Hartel, G. \& Lonhija, A. (1970) Acta Med. Scand. 188, 257-264.

28. Van Waes, L. \& Lieber, C. S. (1977) Br. Med. J. II, 15081510 .
29. Rej, R., Bretaudiere, J. P. \& Graffunder, B. (1981) Clin. Chem. 27, 535-542.

30. Teranishi, H., Kagamiyama, H., Teranishi, K., Wada, H., Yamano, T. \& Morino, Y. (1978) J. Biol. Chem. 253, 88428846.

31. Ideo, G., De Franchis, R., Bellobuono, A., Sforzini, S. \& Dioguardi, N. (1972) J. Clin. Chem. Clin. Biochem. 10, 74-7.6.

32. Rubin, E., Beattie, D. S. \& Lieber, C. S. (1970) Lab. Invest. $23,620-627$.

33. Lieber, C. S. (1977) in: Alcohol and the liver (Fisher, M. M. \& Rankim, J. C., eds.) Plenum, New York, 197.

34. Svoboda, D. J. \& Manning, R. T. (1964) Am. J. Pathol. 44, 645-662.

35. Martin, F. C., Slavin, G. \& Levi, A. J. (1982) Br. Med. Bull. $38,53-56$.
Dr. Mauro Panteghini

1 st Laboratory of Clinical Chemistry

Spedali Civili

I-25100 Brescia 